Vol. 3 No. 2 Agustus 2019

ISSN 2580-5029

\title{
Perubahan Kualitas Sperma Mencit (Mus musculus) Yang Terpapar Asap Rokok Elektrik
}

\author{
Andita Ayu Mandasari ${ }^{1}$, Siti Nur Asiyah'2, Kurnia Lintang1 \\ ${ }^{1}$ Universitas Maarif Hasyim Latif, Sidoarjo, Indonesia \\ 2 UIN Sunan Ampel, Surabaya, Indonesia \\ *st.nurasiyah@uinsby.ac.id
}

\begin{abstract}
Smoking is one of the habits that can affect human health. One type of cigarette that is currently the choice is electric cigarettes. The e-cigarette content includes nicotine, propylene glycol, flavorings and glycerin. The purpose of this study was to determine the effect of exposure to ecigarette smoke on mice strain balb / $c$ with the parameters of the number of spermatozoa. This study used 15 male mice which were 8-10 weeks old and weighed 25-30 grams of male mice which were divided into 3 treatment groups namely control group, treatment group one and treatment group two. In the control group no exposure to cigarette smoke was carried out while in the treatment group one was exposed to cigarette smoke in mice with a dose of $0 \mathrm{mg}$ nicotine and the second treatment group was exposed to e-cigarette smoke at a dose of $18 \mathrm{mg}$ nicotine. Electric cigarette smoke exposure is carried out for 30 days using a suction device from a syringe. The exposure of cigarette smoke is carried out every day with successive doses of 20 times as much as 3 times with a time lag of 10 minutes ( 5 minutes the chamber is closed and 5 minutes of the chamber is opened). The results showed that the average number of spermatozoa in the control group was 16.816 million / ml. The average number of spermatozoa in treatment one was 10.432 million / ml and the average number of spermatozoa in treatment two was 5.234 million / ml. This shows that exposure to cigarette smoke can reduce the number of spermatozoa from the control group to the first treatment by $42.56 \%$ and the second treatment shows a decrease from the first group by $34.65 \%$.
\end{abstract}

Keywords: Electric Cigarette, Mice, Amount of Spermatozoa

\begin{abstract}
ABSTRAK
Kesehatan dapat terganggu karena kebiasaan merokok. Salah satu jenis rokok yang menjadi pilihan saat ini yaitu rokok elektrik. Kandungan rokok elektrik meliputi nikotin, propilen glikol, perasa dan gliserin. Tujuan penelitian ini untuk mengetahui adanya pengaruh paparan asap rokok elektrik pada mencit strain balb/c dengan parameter jumlah spermatozoa. Penelitian ini menggunakan mencit jantan sebanyak 15 ekor yang berumur 8-10 minggu dengan berat mencit jantan 25-30 gram dan dibagi menjadi tiga kelompok, yang terdiri dari kelompok control, kelompok perlakuan satu serta kelompok perlakuan dua. Pada kelompok kontrol tidak dilakukan pemaparan asap rokok elektrik sedangkan pada kelompok perlakuan satu dilakukan pemaparan asap rokok pada mencit dengan dosis 0 mg nikotin dan kelompok perlakuan kedua dilakukan pemaparan asap rokok elektrik dengan dosis $18 \mathrm{mg}$ nikotin. Pemaparan asap rokok elektrik dilakukan selama 30 hari dengan menggunakan alat hisap dari spuit. Pemaparan asap rokok dilakukan setiap hari dengan berturut turut dengan dosis 20 kali hisapan sebanyak 3 kali dengan
\end{abstract}


jeda waktu 10 menit (5 menit chamber ditutup dan 5 menit chamber dibuka). Hasil penelitian menunjukan rata rata jumlah spermatozoa pada kelompok kontrol sebesar 16,816 juta/ml. Rata rata jumlah spermatozoa pada perlakuan satu sebesar $10,432 \mathrm{juta} / \mathrm{ml}$ dan rata rata jumlah spermatozoa pada perlakuan dua sebesar 5,234 juta/ml. Hal ini menunjukan bahwa pemaparan asap rokok dapat menurunkan jumlah spermatozoa dari kelompok kontrol ke perlakuan pertama sebesar $42,56 \%$ dan perlakuan kedua menunjukan adanya penurunan dari kelompok pertama sebesar 34,65\%.

Kata Kunci: Rokok Elektrik, Mencit, Jumlah Spermatozoa

\section{PENDAHULUAN}

Merokok telah menjadi salah satu kebiasaan yang dapat berpengaruh terhadap kesehatan manusia. Kebiasaan ini tidak hanya dilakukan pria dewasa tetapi juga wanita dan anak-anak. Setiap tahun, jumlah perokok di dunia akan terus bertambah karena terjadi peningkatan jumlah populasi. Menurut World Health Organization (WHO) pada tahun 2013, penggunaan rokok di dunia sebanyak 32,9\% pria dan $18,4 \%$ wanita dari total penduduk di dunia. Lebih dari $80 \%$ perokok di seluruh dunia berada di negara berkembang. Pada tahun 2008, jumlah konsumen rokok di Indonesia menduduki peringkat nomor tiga terbesar di dunia setelah Cinda dan India.Data Kementerian Kesehatan menunjukkan peningkatan prevalensi perokok dari tahun 1995 sebanyak 27\% dan pada tahun 2013 meningkat menjadi 36,3\%. Keadaan ini semakin mengkhawatirkan karena prevalensi perokok perempuan mengalami kenaikan pada tahun 1995 sebesar $4,2 \%$ menjadi sebesar $6,7 \%$ di tahun 2013. Tingginya jumlah perokok aktif berbanding lurus dengan jumlah perokok pasif yang terpapar asap rokok orang lain(World Health Organization, 2013).
Jenis rokok terus mengalami perkembangan inovasi, salah satunya adalah rokok elektrik.Inovasi baru ini menimbulkan rasa ingin tahu yang tinggi dari beberapa kalangan. Rokok elektrik ini dipercaya lebih aman dan lebih stylishserta tidak mengurangi sensasi kenikmatan merokok seperti rokok konvensional. Inovasi rokok elektrik pada awalnya digunakan sebagai salah satu alat bantu berhenti merokok atau terapi pengganti nikotin (Nicotine Replacement Therapy, NRT) dengan cara mengurangi kadar nikotin rokok elektrik secara bertahap di bawah supervisi dokter. Namun pada tahun 2010, WHO tidak lagi merekomendasi penggunaannya sebagai NRT karena beberapa studi menemukan kandungan zat pada cairan rokok elektrik seperti propilen glikol, gliserin, nikotin, ekstrak tembakau, perasa yang dapat menjadi racun dan karsinogen sehingga dinyatakan tidak memenuhi unsur keamanan (Badan Pengawas Obat dan Makanan, 2015).

Penelitian yang dilakukan oleh Food and Drug Administration (FDA) di Amerika pada tahun 2009 tentang rokok elektrik menyebutkan bahwa terdapat zat karsinogen pada rokok elektrik yang disebut dengan Diethylene Glycol (DEG) dan Tobacco Spesific 
Nitrosamin (TSNA) yng bersifat toksik. Hasil penelitian ini mendorong FDA untuk mengeluarkan peringatan kepada masyrarakat tentang bahaya rokok elektrik yang mengandung zat tosik dan bersifat karsinogen. Hal ini membuat adanya kebijakan pembatasan penjualan dan distribusi rokok elektrik di beberpa Negara, seperti di Amerika (FDA, 2011). Masyarakat Indonesia juga telah diperingatkan oleh Badan Pengawas Obat dan Makanan untuk tidak menggunakan rokok elektrik karena rokok elektrik dapat lebih berbahaya dibandingkan dengan rokok konvensional (Bam et al., 2014).

Spermatogenesis adalah suatu proses perkembangan dari spermatongia yang berasal dari epitel tubulus seminiferus yang berproliferasi dan berubah menjadi spermatozoa.Siklus spermatogenesis pada mencit hamper sama dengan yang terjadi pada mamalia. Satu siklus spermatogenesis di tubulus seminiferi sampai dilepaskannya spermatozoa ke lumen seminiferi pada mencit adalah berkisar 35,5 hari atau kurang dari 5 minggu (Rugh, 1968). Sperma dikatakan mempunyai kualitas yang baik apabila mampu membuahi ovum. Salah satu indikator fertil atau tidak adalah dengan melihat kualitas spermanya. Kualitas sperma ini dapat ditentukan melalui pemeriksaan makroskopis atupun mikrokopis dengan melihat jumlah, morfologi dan motilitas spermatozoa(Nasution, 1999).

Jumlah spermatozoa dihitung dengan cara melihat jumlah spermatozoa per $\mathrm{ml}$ http://jurnalsaintek.uinsby.ac.id/index.php/biotropic ejakulat dan jumlah spermatozoa per volume ejakulat. Namun, yang umum dipakai adalah jumlah spermatozoa per ml ejakulat(Yatim, 1994).

Penelitian yang dilakukan oleh (Badan Pengawas Obat dan Makanan, 2015) Rajpurkar dkk. (2000) pada hewan percobaan, didapatkan bahwa pemaparan asap rokok selama 30 hari dapat menyebabkan penurunan jumlah spermatid. Tikus yang terpapar asap rokok selama 45 hari mengalami penurunan diameter tubulus seminiferous sehingga jumlah spermatozoa yang dihasilkan akan lebih sedikit. Terganggunya spermatogenesis di tubulus seminiferus mengakibatkan penurunan kualitas sperma sehingga menyebabkan infertil.

Penelitian yang dilakukan oleh Tooy M, et all (2016) juga menyatakan hasil yang sama. Paparan asap rokok elektrik selama 50 hari yang diberikan kepada 9 ekor tikus wistar jantan (Rattus norvegicus) menyebabkan penurunan kualitas spermatozoa. Berdasarkan hal tersebut maka peneliti ingin menganalisis apakah ada efek asap rokok elektrik terhadap jumlah spermatozoa pada mencit.

Penelitian ini bertujuan untuk mengetahui jumlah spermatozoa mencit yang dipapar asap rokok elektrik dengan $0 \mathrm{mg}$ nikotin dan untuk mengetahui jumlah spermatozoa mencit yang dipapar asap rokok elektrik dengan 18 mg nikotin. 


\section{METODE}

Penelitian ini merupakan jenis penelitian eksperimental dan data diperoleh dari hasil pemeriksaan laboratorium dengan menggunakan metode haemacytometer (kamar hitung).

Populasi dalam penelitian ini yaitu mencit jantan strain Balb/C yang diperoleh dari Institute of Tropical Disease (ITD) Universitas Airlangga Surabaya. Sampel yang dipakai yaitu mencit jantan strain Balb/C berjumlah 15 mencit dan dibagi menjadi 3 kelompok. Tiap kelompok perlakuan terdapat 5 mencit, dengan rincian sebagai berikut:

1. Kelompok kontrol :Mencit tanpa diinhalasi asap rokok.

2. Perlakuan pertama : Mencit diinhalasi asap rokok elektrik tanpa kandungan nikotin (0 mg nikotin)

3. Perlakuan kedua : Mencit diinhalasi asap rokok elektrik dengan kadar nikotin $18 \mathrm{mg}$.
Tempat penelitian di Laboratorium Fakultas Ilmu Kesehatan Universitas Ma'arif Hasyim Latif Sidoarjo. Penelitian dilakukan tanggal 24 Januari - 03 Maret 2018. Pengambilan sampel dilakukan setelah mencit dipapar asap rokok elektrik selama 30 hari.

\section{HASIL DAN PEMBAHASAN}

Hasil pemeriksaan sampel sperma tentang jumlah spermatozoa pada mencit yang terpapar asap rokok elektrik dalam waktu 30 hari dengan mencit yang tidak terpapar asap rokok elektrik (kontrol). Mencit dipapar asap rokok elektrik dengan 0 mg nikotin (P1) dan mencit yang dipapar asap rokok elektrik dengan kadar nikotin 18 mg nikotin (P2) terdapat perbedaan yang bermakna.

Tabel 1. Rata Rata Jumlah Spermatozoa Mencit Setelah Pemaparan Asap Rokok Elektrik Selama 30 Hari

\begin{tabular}{|c|c|c|c|c|c|c|c|}
\hline \multirow{2}{*}{ No } & \multirow{2}{*}{ Kelompok } & \multicolumn{5}{|c|}{ Ulangan (Juta/ml) } & \multirow{2}{*}{$\begin{array}{l}\text { Rata Rata Jumlah } \\
\text { Spermatozoa } \\
\text { (Juta/ml) }\end{array}$} \\
\hline & & 1 & 2 & 3 & 4 & 5 & \\
\hline 1 & Kontrol & 15,18 & 18,03 & 25,2 & 14,91 & 10,74 & $16,816 \pm 5,3$ \\
\hline 2 & Perlakuan 1 & 13,78 & 6,49 & 6,54 & 12,94 & 12,4 & $10,432 \pm 3,6$ \\
\hline 3 & Perlakuan 2 & 2,76 & 10,12 & 7,13 & 3,22 & 2,94 & $5,234 \pm 2,9$ \\
\hline
\end{tabular}

Sumber: Data hasil pemeriksaan laboratorium, 2018

Berdasarkan tabel di atas, diketahui bahwa jumlah spermatozoa mencit dipengaruhi oleh asap rokok elektrik. Pada kelompok kontrol rata rata jumlah http://jurnalsaintek.uinsby.ac.id/index.php/biotropic spermatozoa sebesar 16,816 juta/ml dengan standart devisiasi $\pm 5,3$. Pada perlakuan 1 rata rata jumlah spermatozoa sebesar 10,432 
juta/ml dengan standar devisiasi $\pm 3,6$ dan perlakuan 2 rata rata jumlah spermatozoa sebesar 5,234 juta/ml dengan standar devisiasi $\pm 2,9$.

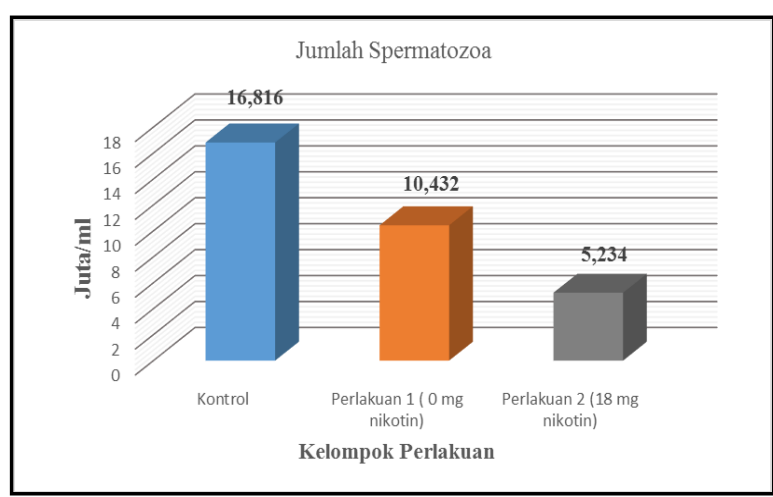

Gambar 1. Grafik hasil pemeriksaan laboratorium, 2018.

Dari grafik di atas, diketahu bahwa pada diagram warna biru (kelompok kontrol) menunjukkan jumlah spermatozoa sebesar 16,816 juta/ml. Pada diagram yang bewarna orange (perlakuan 1) menunjukan jumlah spermatozoa sebesar 10,432 juta/ml. Pada diagram yang bewarna abu abu (perlakuan 2) menunjukan jumlah spermatozoa sebesar 5,234 juta/ml. Perlakuan 1 mengalami penurunan dari kelompok kontrol sebesar $42,56 \%$ dan perlakuan 2 mengalami penurunan dari perlakuan 1 sebesar 34,65\% sedangkan dari kelompok kontrol ke perlakuan 2 mengalami penurunan jumlah spermatozoa sebesar 77,21\%.

Merokok telah menjadi salah satu kebiasaan yang dapat berpengaruh terhadap kesehatan manusia. Kebiasaan ini tidak hanya dilakukan pria dewasa tetapi juga wanita dan anak-anak. Salah satu jenis rokok yang tengah menjadi fenomena baru di tengah masyarakat Indonesia adalah rokok elektrik. Rokok elektrik digunakan karena dianggap lebih aman dan lebih stylish dalam penggunaannya, tetapi WHO tidak merekomendasikan penggunaan dari rokok elektrik karena beberapa penelitian menyebutkan bahwa di dalam rokok elektrik terdapat beberapa zat berbahaya seperti propilen glikol, gliserin, nikotin, ekstrak tembakau dan zat perasa yang dapat menjadi zat karsinogen sehingga tidak memenuhi unsure keamanan (Badan Pengawas Obat dan Makanan, 2015).

Dari hasil penelitian yang telah dilakukan, pada kelompok kontrol jumlah spermatozoa sebesar 16,816 juta/ml. Pada perlakuan 1 (pemaparan asap rokok elektrik dengan kandungan $0 \mathrm{mg}$ nikotin) jumlah spermatozoa sebesar 10,432 juta/ml. Pada perlakuan pertama mengalami penurunan dari kelompok kontrol sebanyak 42,56\%. Hal ini bisa disebabkan karena kandungan nikotin yang tertera pada label liquid atau cairan rokok elektrik tidak sesuai dengan kadar yang sebenarnya karena BPOM telah menguji laboratorium terhadap tujuh merek liquid rokok elektronik yang dijual melalui kedai rokok dan secara online. Dari rokok elektrik yang diuji didapatkan bahwa ada 4 merek yang menunjukkan hasil kadar nikotin tidak sama dengan apa yang tertulis di label kemasan dengan simpangan deviasi sebesar 12,8\%-19,8\% (Badan Pengawas Obat dan Makanan, 2015). Selain itu, penurunan jumlah spermatozoa bisa juga disebabkan karena adanya kandungan propilen glikol 
yang ada pada cairan rokok elektrik sehingga pada saat dihirup dapat menimbulkan gangguan pada sistem reproduksi.

Data perlakuan kedua (Pemaparan asap rokok elektrik dengan kandungan $18 \mathrm{mg}$ nikotin) menunjukkan jumlah spermatozoa sebesar 5,234 juta /ml. Hal ini berbeda nyata dengan kelompok perlakuan pertama dengan penurunan sebesar 34,65\%. Hal ini bisa disebabkan karena kandungan nikotin dengan jumlah yang besar yaitu $18 \mathrm{mg}$. Kandungan cairan rokok elektrik seperti nikotin yang bila dibakar akan menghasilkan radikal bebas merupakan bahan toksik bilamana masuk kedalam tubuh. Radikal bebas mempunyai reaktivitas yang tinggi. Reaktivitas yang dihasilkan oleh radikal bebas dapat merusak protein, karbohidrat, lemak dan asam nukleat. Radikal bebas terdapat secara fisiologis pada sperma manusia. Timbulnya radikal bebas dalam tubuh diimbangi dengan mekanisme pertahanan endogen dengan memproduksi zat yang mempunyai pengaruh sebagai anti radikal bebas yang disebut antioksidan, tetapi apabila produksi radikal bebas atau oksigen reaktif (ROS) meningkat melebihi dari sistem pertahan antioksidan tubuh maka akan menimbulkan stres oksidatif. Stres oksidatif dapat menyebabkan kerusakan pada membran sel sehingga akan terjadi penurunan pada morfologi, motilitas dan konsentrasi spermatozoa (Tooy et al., 2016).

Stres oksidatif merupakan kondisi dimana terjadi peningkatan ROS. Pada kondisi stres oksidatif, radikal bebas dapat http://jurnalsaintek.uinsby.ac.id/index.php/biotropic mengakibatkan kerusakan sel melalui tiga cara, yaitu : peroksidasi lipid membran sel yang menyebabkan kerusakan membran sel, kerusakan DNA yang mengakibatkan mutasi DNA bahkan kematian sel, dan modifikasi protein teroksidasi (Fauzi, 2008)(Kumar et al., 2005). Radikal bebas merupakan salah satu target dari senyawa lipid, protein, asam lemah tak jenuh, lipoprotein, karbohidrat, serta DNA dan RNA. Molekul yang paling rentan terhadap radikal bebas yaitu asam lemak tak jenuh yang terdapat didalam sel (Fauzi, 2008). Kerusakan sel akibat serangan radikal bebas yang paling awal diketahui perosidase lipid. Hal ini akan memicu terjadinya reactive Oxygen Species (ROS). Aktivitas ROS yang berlebih dapat meningkatkan stress oksidatif yaitu suatu keadaan dimana tidak terjadi keseimbangan antara proksidan dan antioksidan (Siregar, 2009) akibat adanya radikal bebas didalam tubuh maka akan terjadi gangguan penyakit dalam saluran reproduksi, salah satunya yaitu gangguan pada organ reproduksi. Pada keadaan normal terdapat keseimbangan anatara ROS dan aktivitas antioksidan dalam reproduksi jantan namun pada kondisi patologis misalnya paparan dari asap rokok atau polusi menyebabkan produksi ROS akan meningkat sehingga mengganggu keseimbangan sistem proksidan. Selanjutnya, spermatozoa mengalami stress oksidatif sehingga spermatozoa kehilangan motilitas, viabilitas, jumlah dan kerusakan morfologi (Intani, 2010). 
Hasil penelitian ini sesuai dengan penelitian yang dilakukan oleh Karim D (2011), bahwa 30 mencit jantan (Mus musculus L) yang terpapar asap rokok elektrik selama 15 hari menunjukkan terjadinya penurunan kualitas spermatozoa. Hal ini terjadi karena adanya produk radikal bebas yang dikeluarkan oleh rokok elektrik.

Jumlah spermatozoa yang dihasilkan oleh testis sangat tergantung pada mekanisme secara langsung terhadap spermatogenesis di dalam tubulus seminiferus. Apabila spermatogenesis berlangsung normal, maka akan dihasilkan jumlah spermatozoa yang normal, bila spermatogenesis berlangsung tidak normal maka akan dihasilkan jumlah spermatozoa yang tidak normal. Seperti yang kita ketahui, jika didalam tubuh kita terdapat radikal bebas yang berlebih maka akan mengganggu proses spermatogenesis.

Hasil penelitian yang dilakukan oleh Jems membuktikan bahwa pemaparan asap rokok dapat menurunkan konsentrasi spermatozoa dan viabilitas spermatozoa serta meningkatkan abnormalitas spermatozoa. Peningkatan dan penurunan tersebut sejalan dengan lamanya pemaparan asap rokok. Penurunan kualitas spermatozoa diduga akibat radikal bebas asap rokok yang bersifat sitotoksik (Jems et al., 2014). Penelitian yang dilakukan Nor Aina (2005) menyebutkan bahwa, paparan asap rokok dapat menghambat proses spermatogenesis secara nyata yang ditandai dengan penurunan jumlah sel-sel spermatogonium, spermatosit primer, spermatid dan lapisan sel spermatogenik serta penurunan kualitas spermatozoa secara nyata yang ditandai dengan penurunan prosentase spermatozoa normal, kecepatan gerak spermatozoa, motilitas spermatozoa dan spermatozoa hidup.

\section{KESIMPULAN}

Sesuai dengan tujuan peneltian, penelitian ini menghasilkan temuan bahwa ada pengaruh jumlah spermatozoa mencit yang dipapar asap rokok elektrik dengan 0 mg nikotin dengan penurunan jumlah spermatozoa sebesar $42,56 \%$ dibandingkan kelompok control dan ada pengaruh jumlah spermatozoa mencit yang dipapar asap rokok elektrik dengan kandungan 18 mg nikotin dengan penurunan jumlah spermatozoa sebesar 77,21\% dibandingkan kelompok Kontrol.

Dari hasil penelitian ini, peneliti dapat memberikan rekomendasi kepada masyarakat terutama bapak bapak, anak muda maupun anak anak agar tidak menggunakan dan memakai rokok elektrik. Sedangkan, untuk mahasiswa, diharapkan dilakukan penelitian lebih lanjut tentang pemeriksan sitologi terhadap testis.

\section{DAFTAR PUSTAKA}

Badan Pengawas Obat dan Makanan, 2015. Bahaya Rokok Elektronik Racun Berbalut Teknologi. Jakarta.

Bam, T., Bollow, W., Berezhnova, I., JacksonMoris, A., Jones, A., Latif, E., 2014. Position statement on electronic 
cigarette or electronic nicotine delivery systems. Int J Tuberc Lung Dis 18, 5-7.

Fauzi, T.M., 2008. Aktivitas Radikal Bebas Pada Hepar Tikus. Fakultas Kedokteran Universitas Brawijaya, Malang.

FDA, 2011. Flavored Tobacco. http://www.fda.gov/TobaccoProd ucts/ProtectingKidsfromTobacco/ FlavoredTobacco/default.htm

Intani, Y., 2010. Pengaruh Timbal (Pb) Pada Ujara Jalan Tol Terhadap Gambaran Mikroskopis Testis Dan Kadar Timbal $(\mathrm{Pb})$ Dalam Darah Mencit Balb/c Jantan. Universitas Diponegoro, Semarang.

Jems, A., Kusumorini, N., Agungpriyono, S., Sismin, A., S., 2014. Perubahan Kualitas Spermatozoa Dan Jumlah Sel-Sel Spermatogenik Tikus Yang Terpapar Asap Rokok .

Karim, Darwin. 2011. Pengaruh Paparan Asap Rokok Elektrik Terhadap Motilitas, Jumlah Sel Sperma dan Pengaruh Paparan Asap Rokok Elektrik Terhadap Motilitas, Jumlah Sel
Sperma dan Kadar MDA Testis Mencit Jantan (Mus musculus L). Universitas Sumatera Utara. Tesis

Nasution, A., 1999. Andrologi. Fakultas Kedokteran Universitas Andalas, Padang.

Siregar, J.H., 2009. Pengaruh Pemberian Vitamin C Terhadap Jumlah Sel Leydig Dan Jumlah Sperma Mencit Jantan Yang Dipapar Monosodium Glutamate (MSG). Universitas Sumatra Utara, Medan.

Tooy, M., Departemen Biologi Fakultas MIPA, L., Satiawati, L., 2016. Perbandingan kualitas spermatozoa tikus wistar (rattus norvegicus) yang diberi paparan asap rokok dengan asap rokok elektronik. J. E-Biomedik EBM .

World Health Organization, 2013. Media Centre: Fact Sheets of Tobacco. http://www.who.

int/mediacentre/factsheets/fs339 /en/

Yatim, W., 1994. Reproduksi dan Embriologi. Tarsito, Bandung. 